\title{
Possible Role of Extracellular Membrane Particles in Hydrocarbon Utilization by Acinetobacter calcoaceticus 69-V
}

\author{
By REINER CLAUS†, OTHMAR KÄPPELI* AND ARMIN FIECHTER \\ Institute of Biotechnology, Swiss Federal Institute of Technology, Hönggerberg, 8093 Zürich, \\ Switzerland
}

(Received 10 October 1983; revised 2 December 1983)

\begin{abstract}
Extracellular membrane particles were isolated from the cell-free culture liquid of Acinetobacter calcoaceticus $69-\mathrm{V}$ grown on $\mathrm{n}$-alkanes. It was demonstrated by means of an antiserum raised against intact cells of $A$. calcoaceticus $69-\mathrm{V}$ grown on hexadecane that the particles were probably derived from the surface membrane fraction of the bacteria. The accumulation by the bacteria of radioactivity originating from $\left[{ }^{14} \mathrm{C}\right]$ hexadecane solubilized in the particles was studied. The apparent $K_{\mathrm{m}}$ value for the uptake of solubilized hexadecane was $33 \mu \mathrm{M}$ and the $V_{\max }$ value was $1.2 \times 10^{-9} \mathrm{~mol} \mathrm{~min}^{-1}$ (mg bacterial protein) ${ }^{-1}$. The $K_{\mathrm{m}}$ value for the uptake of free hexadecane was approximately 10 times higher, indicating the possible role of particles as transport vehicles for the insoluble substrate. Accumulation of radioactivity was inhibited by KCN and $\mathrm{NaN}_{3}$, suggesting an energy-dependent uptake process.
\end{abstract}

\section{INTRODUCTION}

For micro-organisms growing on water-insoluble substrates such as hydrocarbons the primary problem is mass-transfer of the substrate from the medium to the cell interior. This transfer can depend on the dispersion of the substrate by mechanical means. However, some adaptation mechanisms of the organism itself can also account for the uptake of insoluble substrates and have been described in the literature. Hydrocarbon-induced chemical and structural alterations at the surface of Candida tropicalis have been described by Käppeli et al. (1978). Furthermore, several authors have reported the isolation of biological compounds affecting the water solubility of alkanes. A trehalose lipid has been isolated from the growth medium of bacteria, especially Nocardia spp. grown on n-alkanes (Suzuki et al., 1969; Rapp \& Wagner, 1976). An extracellular rhamnolipid produced by Pseudomonas aeruginosa when the bacteria were grown on a mixture of n-alkanes has also been described (Itoh et al., 1971). Hisatsuka et al. (1977) described a 'protein-like activator' for n-alkane oxidation. Emulsifiers, consisting of complex mixtures of protein, lipid and carbohydrate, have been isolated from cultures of Corynebacterium hydrocarboclastus by Zajic et al. (1977). Käppeli \& Finnerty (1979) related the partition of hexadecane in the growth medium of hexadecane-growing Acinetobacter sp. to the accumulation of an extracellular vesicular component. This component was found to consist of particles containing proteins, lipopolysaccharides and phospholipids, and had a polypeptide composition similar to that of the outer membrane of the bacteria. In this paper we report on the isolation of extracellular particles from the culture liquid of $A$. calcoaceticus grown on n-alkanes, and demonstrate the functional role of these particles in hydrocarbon uptake.

\section{METHODS}

Growth of bacterium. Acinetobacter calcoaceticus $69-\mathrm{V}$ was purchased from the Karl-Marx University of Leipzig. Growth was carried out in continuous culture on minimal medium, as described by Kleber \& Aurich (1973), using

† Present address : Department of Biological Sciences, Karl-Marx University Leipzig, 7010 Leipzig, Talstrasse 33 , German Democratic Republic. 
a hydrocarbon mixture $\left(\mathrm{C}_{12}-\mathrm{C}_{18}\right)$ as the sole carbon source. A chemostat ( 21 bioreactor KLF 2000; Bioengineering, Wald, Switzerland) was used, with a working volume of 1.51 and a dilution rate $(D)$ of $0.2 \mathrm{~h}^{-1} ; \mathrm{pH}_{5} \cdot 5 ; S_{0}$ $10 \mathrm{~g} \mathrm{l}^{-1}$; agitation, 1000 r.p.m.; aeration, $100 \mathrm{l} \mathrm{h}^{-1}$; temperature, $30^{\circ} \mathrm{C}$.

Immunological methods. An antiserum raised against whole cells of $A$. calcoaceticus $69-\mathrm{V}$ grown on hexadecane was prepared as described by Claus \& Kleber (1981). The double diffusion test of Ouchterlony was performed in agarose gels $\left(10 \mathrm{~g}^{-1}\right)$ as described by Claus (1979).

For the Ouchterlony test a membrane fraction corresponding to the outer membrane of the bacterium was isolated from hydrocarbon-grown cells as described by Scott et al. (1976).

Preparation of the extracellular particle fraction. Culture from the chemostat was collected and cells were removed by centrifugation at $6000 \mathrm{~g}$ for $15 \mathrm{~min}$ at $4{ }^{\circ} \mathrm{C}$. The resulting supernatant was subsequently filtered through glass filters (Sartorius S 13400) and membrane filters (Sartorius; pore sizes $3 \mu \mathrm{m} ; 0.8 \mu \mathrm{m}$ and $0.45 \mu \mathrm{m}$ ). The filtrate was concentrated by pressure filtration (XM-50; Amicon), and then particles were recovered by centrifugation at $100000 \mathrm{~g}$ for $60 \mathrm{~min}$ at $4{ }^{\circ} \mathrm{C}$.

Solubilization of hexadecane in the particle fraction. Solubilization of hexadecane takes place by the partition of hydrophobic hexadecane molecules into the lipophilic interior of the particles. This solubilized hexadecane remains within the particle fraction when it is isolated from the liquid phase by high-speed centrifugation (Käppeli \& Finnerty, 1979). Hexadecane-containing particles were prepared as follows. The particles ( $4.5 \mathrm{mg}$ protein) were resuspended in $200 \mathrm{ml} 50 \mathrm{~mm}$-phosphate buffer $(\mathrm{pH} 7 \cdot 5)$ and incubated with $30 \mu \mathrm{l}\left[1-{ }^{14} \mathrm{C}\right]$ hexadecane (specific activity $1.98 \mathrm{GBq} \mathrm{mmol}^{-1}$ ) and $20 \mu \mathrm{l}$ of unlabelled hexadecane at $30^{\circ} \mathrm{C}$ in a shaking waterbath for $60 \mathrm{~min}$. After this the suspension was cooled on ice and filtered through a Sartorius membrane filter $(0.45 \mu \mathrm{m}$ pore size) in order to remove the free hexadecane (Käppeli \& Finnerty, 1980). The filtrate was concentrated by pressure filtration (XM-50; Amicon) and used in the uptake studies.

Transport assay. For transport studies, cells were harvested from the continuous culture by centrifugation at $6000 \mathrm{~g}$ for $15 \mathrm{~min}$ at $4^{\circ} \mathrm{C}$. The cells were washed three times with phosphate buffer $(50 \mathrm{mM}, \mathrm{pH} 7 \cdot 5)$. The washed cells were resuspended in the same buffer, brought to an $A_{600}^{1 \mathrm{~cm}}$ value of 15 and preincubated for $15 \mathrm{~min}$ at $30^{\circ} \mathrm{C}$. To a particle-solubilized hexadecane suspension $(4.5 \mathrm{ml}), 0.5 \mathrm{ml}(3.75 \mathrm{mg}$ dry cell wt) bacterial suspension was added. Incubation was carried out in a shaking waterbath at $30^{\circ} \mathrm{C}$. Samples of $200 \mu 1$ were removed at intervals of 5,10 , $15,20,30$ and $40 \mathrm{~min}$ and filtered through Sartorius membrane filters (pore size $0.45 \mu \mathrm{m}$ ) with suction. The filter was subsequently washed wtih $2 \mathrm{ml}$ Tween $80\left(10 \mathrm{~g} \mathrm{l}^{-1}\right), 2 \mathrm{ml}$ propan-2-ol and $5 \mathrm{ml}$-pentane in order to remove the adsorbed hexadecane from the bacteria and from the filter (Käppeli \& Finnerty, 1979). After washing, the filter was put into a counting vial with $5 \mathrm{ml}$ of scintillation fluid (Aqualuma Plus, Lumac B.V., Holland). After the filter disintegrated (usually overnight) the vials were counted in a Packard-Tri-Carb, model 2650 Liquid Scintillation Spectrometer for $5 \mathrm{~min}$. From the measured radioactivity (d.p.m.) hexadecane uptake was calculated and expressed in pmol $\mathrm{min}^{-1}(\mathrm{mg} \text { bacterial protein })^{-1}$. Incubation conditions for measurements using free hexadecane were exactly as described above. Incubation was carried out in a $4.5 \mathrm{ml} 50 \mathrm{~mm}$-phosphate buffer (pH 7.5) with $0.3 \mu \mathrm{l}\left[1{ }^{14} \mathrm{C}\right]$ hexadecane (specific activity $1.98 \mathrm{GBq} \mathrm{mmol}^{-1}$ ) and $0.2 \mu \mathrm{l}$ unlabelled hexadecane.

Controls were done with heat-denatured cells $\left(15 \mathrm{~min}\right.$ at $\left.65^{\circ} \mathrm{C}\right)$, and all results were corrected for background (less than 30 d.p.m.). All calculations were made from triplicate measurements.

Protein determination. Protein was estimated by the Lowry method using bovine serum albumin as the standard.

\section{RESULTS}

\section{Immunological properties of the particle fraction}

With the same procedures that Käppeli \& Finnerty (1979) used to prepare extracellular particles from Acinetobacter sp., we succeeded in isolating particles from the culture liquid of $A$. calcoaceticus $69-\mathrm{V}$ growing on $\mathrm{n}$-alkanes in continuous culture. Based on the similarity in phospholipid and protein composition, it was postulated that the extracellular particles were derived from the outer membrane of the bacterium (Käppeli \& Finnerty, 1979). Immunological studies using an antiserum prepared with intact cells of $A$. calcoaceticus have now added further evidence to this assumption. The antiserum was tested against the particle fraction and the outer membrane fraction of the bacterium, both solubilized in buffer containing $0.05 \%$ Tween 80 . With the extracellular particle fraction, two precipitation bands were formed while with the cellular membrane fraction, only one band appeared (Fig. 1). The second precipitation band with the particle fraction is possibly due to the nonhomogenous size of the particles (Käppeli \& Finnerty, 1979). The absence of spurs points to identical immunological determinants in the vesicular and membrane fractions. 


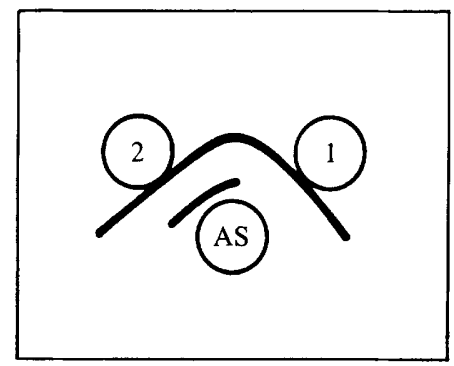

Fig. 1. Line tracing of an Ouchterlony double diffusion test in agarose gel $\left(10 \mathrm{~g} \mathrm{l}^{-1}\right) .1,20 \mu \mathrm{l}(0 \cdot 15 \mathrm{mg}$ protein) membrane fraction; $2,20 \mu \mathrm{l}(0.05 \mathrm{mg}$ protein) particle fraction; AS, $20 \mu \mathrm{l}$ antiserum against whole cells of $A$. calcoaceticus $69-\mathrm{V}$.

Table 1. Inhibition of the uptake of free and solubilized hexadecane by $\mathrm{NaN}_{3}$ and $\mathrm{KCN}$

Measurements were taken after an incubation period of $15 \mathrm{~min}$.

\begin{tabular}{|c|c|c|c|c|}
\hline \multirow[b]{2}{*}{$\begin{array}{l}\text { Inhibitor } \\
(3.3 \mathrm{~mm})\end{array}$} & \multicolumn{2}{|c|}{ Free hexadecane } & \multicolumn{2}{|c|}{$\begin{array}{l}\text { Particle-solubilized } \\
\text { hexadecane }\end{array}$} \\
\hline & $\begin{array}{c}\text { Uptake rate } \\
\text { [pmol (mg bacterial } \\
\text { protein })^{-1} \text { per } 15 \mathrm{~min} \text { ] }\end{array}$ & $\begin{array}{c}\text { Inhibition } \\
(\%)\end{array}$ & $\begin{array}{c}\text { Uptake rate } \\
\text { [pmol (mg bacterial } \\
\left.\text { protein })^{-1} \text { per } 15 \mathrm{~min}\right]\end{array}$ & $\begin{array}{c}\text { Inhibition } \\
(\%)\end{array}$ \\
\hline None & 210 & - & 345 & - \\
\hline $\mathrm{NaN}_{3}$ & 120 & 43 & 165 & 52 \\
\hline $\mathrm{KCN}$ & 30 & 86 & 45 & 87 \\
\hline
\end{tabular}

Kinetics of particle-solubilized hexadecane uptake by whole cells of A. calcoaceticus 69-V

In order to assess the possible role of excreted particles in hydrocarbon utilization, radioactively labelled hexadecane was solubilized in the extracellular particles, which were subsequently incubated with whole cells. The accumulation of labelled hexadecane was monitored and the amount of particle-derived hexadecane taken up by the cells calculated. The accumulation of hexadecane by the cells versus time was linear during the first 15-20 min of incubation. Later, accumulation reached a constant value, indicating saturation of the system. As a control, bacteria grown on a yeast extract medium were used in the uptake assay. With these cells no incorporation of radioactivity over background values was observed. The uptake system therefore seemed to be induced by the hydrocarbon substrate.

In a further set of experiments, hexadecane accumulation by the cells as a function of the dry cell weight used in the assay was determined. Incorporation of particle-solubilized hexadecane increased linearly with increasing dry cell weights up to a concentration of $0.5 \mathrm{mg} \mathrm{ml}^{-1}$. Further increases in cell density did not increase the amount of cell-associated radioactivity. The reason for this is probably that the substrate transfer was limited by unfavourable biomass/substrate ratios, which prevented saturation of the uptake system. Similar observations were made when hexadecane uptake of the yeast $C$. tropicalis was investigated (Käppeli \& Fiechter, 1981).

When the accumulation of hexadecane by the cells was plotted against the initial concentration of particle-solubilized hexadecane, the system appeared to be saturable. The apparent $K_{\mathrm{m}}$ value for the uptake of particle-solubilized hexadecane was determined from the LineweaverBurk plot to be $33 \mu \mathrm{M}$. The maximum velocity for accumulation was $1.2 \times 10^{-9} \mathrm{~mol} \mathrm{~min}^{-1}(\mathrm{mg}$ bacterial protein $)^{-1}$. When free hexadecane was used in the uptake assay, saturation kinetics were also observed and the corresponding values were $360 \mu \mathrm{M}$ for the $K_{\mathrm{m}}$ value and $0.9 \times$ $10^{-9} \mathrm{~mol} \mathrm{~min}^{-1}$ (mg bacterial protein) ${ }^{-1}$ for the maximal uptake velocity. These data indicate that it is mainly the affinity of the cells towards the substrate which is increased by using particle-solubilized hexadecane for the investigation of the transport.

The presence of $\mathrm{KCN}$ or $\mathrm{NaN}_{3}$ at $3.3 \mathrm{~mm}$ markedly reduced the rate of uptake of hexadecane by the cells (Table 1). KCN caused approximately $85 \%$ inhibition of uptake whereas $\mathrm{NaN}_{3}$ gave 
$50 \%$. When free hexadecane was used in the uptake assays, similar inhibitory effects of $\mathrm{NaN}_{3}$ and $\mathrm{KCN}$ were observed.

\section{DISCUSSION}

The release of particles into the culture medium by bacteria is not unique. Hoekstra et al. (1976) found particles in the culture medium of growing Escherichia coli. The composition of these particles closely resembled that of the outer bacterial membrane (Hoekstra et al., 1976). We have now also been able to show with the use of immunological methods that the isolated particles from $A$. calcoaceticus were most probably derived from the outer membrane of the bacteria.

The possible reason for the increased hydrocarbon uptake rate observed in the presence of the particles is enhancement of the solubility of the substrate and consequently improved interaction with the bacterial outer membrane. Interactions of phospholipid-rich particles with biological membranes are well-known (Gregoriadis, 1976; Jones \& Osborn, 1977 a,b). In the course of such an interaction, penetration of the hexadecane substrate through the membrane may be facilitated and thus the incorporation of hexadecane by the cell. This does not necessarily mean, however, that hexadecane is incorporated unchanged. Enzymic modification of the hexadecane might occur before it finally enters the cell.

Although the precise transport mechanism of alkanes into bacteria is still unknown, the data presented indicate that the particles support the transfer of the substrate from the medium to the cells. The inhibition of uptake by $\mathrm{NaN}_{3}$ and $\mathrm{KCN}$ indicates that transport is an energyrequiring process. Several energy-requiring transformation reactions seem to occur during the transport of the substrate through the membrane (Aurich, 1979). Ruettinger et al. (1977) also described a reversible inhibitory effect of $\mathrm{KCN}$ on the $\omega$-hydroxylase of the n-alkane utilizing bacterium Pseudomonas oleovorans, which was shown to be a membrane-bound enzyme. Hence, inhibition could be a consequence of the action on an enzyme of hydrocarbon metabolism.

\section{REFERENCES}

AURICH, H. (1979). Die Oxydation aliphatischer Kohlenwasserstoffe durch Bakterien. Sitzungsbericht der Akademie der Wissenschaften der DDR; Mathematik-Naturwissenschaften-Technik 16 (N), 3-24.

Claus, R. (1979). Isolierung und Charakterisierung der NADH:Rubredoxin-Oxydoreductase aus Acinetobacter calcoaceticus. Dissertation A, Mathematisch-Naturwissenschaftliche Fakultät, KarlMarx Universität Leipzig, GDR.

Claus, R. \& Kleber, H.-P. (1981). RubredoxinReductase in Rohextrakten von Acinetobacter calcoaceticus in Abhängigkeit von C-Quelle und Wachstumsphase. Zeitschrift für allgemeine Mikrobiologie 21 (10), 729-741.

Gregoriadis, G. (1976). The carrier potential of liposomes in biology and medicine. New England Journal of Medicine 295, 704-710.

Hisatsuka, K., Nakahara, T., Minoda, Y. \& YaMADA, K. (1977). Formation of protein-like activator for n-alkane oxidation and its properties. Agricultural and Biological Chemistry 41, 445-450.

Hoekstra, D., van der LAaN, J. W., DE LeiJ, L. \& Witholt, B. (1976). Release of outer membrane fragments from normally growing Escherichia coli. Biochimica et biophysica acta 455, 889-899.
Itoh, S., Honda, H., Tomrita, F. \& Suzuki, T. (1971). Rhamnolipids produced by Pseudomonas aeruginosa grown on n-paraffin (mixture of $\mathrm{C}_{12}, \mathrm{C}_{13}$ and $\mathrm{C}_{14}$ fractions). Journal of Antibiotics 24, 855-859.

JONES, N. C. \& OSBORN, M. J. (1977a). Interaction of Salmonella typhimurium with phospholipid vesicles. Journal of Biological Chemistry 252, 7398-7404.

JONES, N. C. \& OSBORN, M. J. (1977b). Translocation of phospholipids between the outer and inner membranes of Salmonella typhimurium. Journal of Biological Chemistry 252, 7405-7412.

KäPPELI, O. \& FIECHTER, A. (1981). Properties of hexadecane uptake by Candida tropicalis. Current Microbiology 6, 21-26.

KÄPPELI, O. \& FinNeRTY, W. R. (1979). Partition of alkane by an extracellular vesicle derived from hexadecane-grown Acinetobacter. Journal of Bacteriology 140, 707-712.

KÄPPELI, O. \& FINNERTY, W. R. (1980). Characteristics of hexadecane partition by the growth medium of Acinetobacter sp. Biotechnology and Bioengineering 22, 495-503.

KäPPEli, O., Müller, M. \& Fiechter, A. (1978). Chemical and structural alteration at the cell surface of Candida tropicalis, induced by hydrocarbon substrate. Journal of Bacteriology 133, 952-958. 
KLEBER, H.-P. \& AURICH, H. (1973). Einfluss von nAlkanen auf die Synthese der Enzyme des Glyoxylatzyklus in Acinetobacter calcoaceticus. Zeitschrift für allgemeine Mikrobiologie 13, 473-480.

RAPP, P. \& WAGNER, F. (1976). Formation of trehalose lipid by Nocardia rhodochrous sp. grown on n-alkane. Abstracts of the 5th International Fermentation Symposium, Berlin, p. 133. Berlin: Institut für Gärungsgewerbe und Biotechnologie.

Ruettinger, R. T., Griffith, G. R. \& CoON, M. J. (1977). Characterization of the $\omega$-hydroxylase of Pseudomonas oleovorans as a nonheme iron protein. Archives of Biochemistry and Biophysics 183, 528-537.
Scott, C. C. L., Makula, R. A. \& Finnerty, W. R. (1976). Isolation and characterization of membranes from a hydrocarbon-oxidizing Acinetobacter sp. Journal of Bacteriology 127, 469-480.

Suzuki, T., Tanaka, K., Matsubara, J. \& Kinoshita, S. (1969). Trehalose lipid and $\alpha$-branched- $\beta$-hydroxy fatty acid formed by bacteria grown on n-alkanes. Agricultural and Biological Chemistry 33, 1619-1627.

Zajic, J. E., Guignard, J. \& Gerson, D. F. (1977). Emulsifying and surface active agents from Corynebacterium hydrocarboclastus. Biotechnology and Bioengineering 19, 1285-1301. 